\title{
THE DECISION BY THE INTER-AMERICAN COURT OF HUMAN RIGHTS ON THE AWAS TINGNI VS. NICARAGUA CASE (2001): THE IMPLEMENTATION GAP
}

\author{
FELIPE GÓMEZ ISA ${ }^{1}$
}

\begin{abstract}
In August 2001, the Inter-American Court of Human Rights reached a landmark and pioneering decision in the field of international indigenous peoples' human rights law. However, the case did not end there, but entered a new phase for which neither the community nor their advisors were fully prepared: the implementation phase of the judgment. Our analysis has tried to shed light on the vicissitudes of this long, complex and as yet unfinished process, which is one of the most innovative aspects of this paper. This is particularly relevant given the absence of systematic studies on the implementation processes of judicial decisions made by international bodies (such as the Inter-American Court) from the perspective of the victims themselves, and of the stakeholders involved in the case.
\end{abstract}

Keywords: International Law; human rights; indigenous peoples’ rights; Inter-American Court of Human Rights; Awas Tingni community

Summary: I. INTRODUCTION; II. SOME METHODOLOGICAL CONSIDERATIONS; III. THE DIFFICULT PROCESS OF IMPLEMENTING THE JUDGEMENT; III.1. The Joint Commissions for the Implementation of the Judgment; III.2. The adoption of provisional measures by the Inter-American Court; III.3. Law 445 (2003); III.4. Titling request by the Awas Tingni community; III.5. Dispute settlement stage; III.6. The agreement between the Sandinista National Liberation Front (Frente Sandinista de Liberación Nacional (FLSN)) and YATAMA; III.7. Measuring and marking out stage; III.8. Titling stage; III.9. Title clearance stage; IV. CONCLUSIONS.

\section{INTRODUCTION}

One of the most outstanding features in the field of human rights in recent decades has been the enormous importance acquired by indigenous peoples' rights, both nationally and internationally. These rights have received a degree of legal and jurisprudential recognition that until very recently would have been unthinkable. It is now time to make an honest appraisal of the benefits of these developments and their more than obvious limitations from the perspective of the indigenous peoples themselves. Indigenous peoples continue to face situations of vulnerability and poverty in most of the countries where they live, as well as a growing threat to their lands, territories and natural resources. It is this contrast between legal developments and the daily situations encountered by indigenous peoples that Rodolfo Stavenhagen (2006),

\footnotetext{
${ }^{1}$ Pedro Arrupe Institute of Human Rights, University of Deusto, Bilbao, Spain (felipe.gomez@deusto.es).
} 
the former United Nations Special Rapporteur on the situation of the human rights of indigenous peoples, called "the implementation gap".

Indigenous rights pose a serious challenge to some of the basic theoretical foundations of human rights. Indigenous peoples have repeatedly demanded that their collective rights be recognised. These rights have been alien to the process of the emergence and recognition of human rights in Western legal culture and politics. The multiculturalism that indigenous peoples advocate in addressing human rights clearly challenges a form of human rights that has so far been essentially mono-cultural. Indigenous peoples do not want to maintain their role as mere objects for protection in terms of existing human rights; rather, they want to see the same concept of human rights enhanced by indigenous world views (Gómez Isa, 2014: 723-756). ${ }^{2}$ This is one of the most innovative aspects of the ruling of the Inter-American Court of Human Rights in the Awas Tingni case, as it recognised that the interpretation of the right to property recognised in Article 21 of the American Convention on Human Rights should include the communal forms of property present in indigenous communities. This has caused a kind of indigenisation of the right to property by the Inter-American Court, as shall be seen.

This paper offers a detailed analysis of all the elements involved in the realisation by the Awas Tingni indigenous community that their problem could be framed in terms of human rights. Once they became aware that their rights had been violated, the community and their legal team made the decision to prosecute the case, first before the national courts and then, in the absence of any effective response, before the protection bodies of the Inter-American Human Rights System. In August 2001, the Inter-American Court of Human Rights reached a landmark and pioneering decision in the field of international indigenous peoples' human rights law. However, the case did not end there, but entered a new phase for which neither the community nor their advisors were fully prepared: the implementation phase of the judgment. Our analysis has tried to shed light on the vicissitudes of this long, complex and as yet unfinished process, which is one of the most innovative aspects of this study. This is particularly relevant given the absence of systematic studies on the implementation processes of judicial decisions made by international bodies (such as the Inter-American Court) from the perspective of the victims themselves, and of the stakeholders involved in the case.

Most of the analyses of the effectiveness of the rulings and decisions made by international organs for the protection of human rights warn about an "implementation crisis” (Baluarte and De Vos, 2010: 11), which may undermine the very legitimacy of

\footnotetext{
${ }^{2}$ It is interesting to observe how the indigenous movement has "appropriated" the language of human rights in articulating their local claims. By using the terminology and conceptual framework of Localising Human Rights, indigenous peoples have localised global standards to address their main concerns (Morgan, 2004: 481-500). The latest development in this interesting, although sometimes contradictory process, was the adoption by the United Nations General Assembly of the Declaration on the Rights of Indigenous Peoples on September 13, 2007, after a long and complicated journey in which the indigenous peoples themselves took a leading role, supported by NGOs engaged in human rights and the defence of indigenous rights, as well as by some transnational networks.
} 
such mechanisms. This crisis refers to the scandalously low implementation rates of the decisions of both judicial and quasi-judicial international bodies (the United Nations Committees created by international human rights treaties, for example). States remain reluctant to comply with the judgments and decisions of international organisations, especially when those decisions address issues that those States consider to be sensitive, such as the access of indigenous peoples to land and natural resources.

In addition, the implementation crisis is related to a purely quantitative and formal approach to data about the implementation that has prevailed so far, without considering other more intangible effects that decisions and judgments may have. These intangible effects ${ }^{3}$ may relate to aspects as diverse as: changes in the way public opinion and the institutions involved perceive a given issue that gave rise to a judicial decision or judgment; their impact on the design of certain public policies; and the victims' feeling that a particular decision serves to recognise an injustice. These can result in changes in their relationship with the State; in other words, it can become a source of empowerment and a means to recognise their status as subjects of rights. My paper therefore seeks to fill a gap in the rare studies on implementation conducted to date ${ }^{4}$.

The effectiveness of the international system for the protection of indigenous peoples' human rights rests on a complex process ranging from the local to the global. It depends on a whole set of both legal and non-legal factors and circumstances that need to be understood and analysed. The defence of human rights must be examined as a process involving actors as varied as the victims themselves and their representatives, lawyers, public institutions, non-governmental organisations, and international financial institutions such as the World Bank and the International Monetary Fund, as well as transnational networks ${ }^{5}$, etc. This study deals with the multidimensional scope of this process, including the conditions and circumstances which can promote the success of a strategy to defend human rights in an increasingly globalised world.

\section{SOME METHODOLOGICAL CONSIDERATIONS}

Given the nature of our study of the Awas Tingni case, the methodology employed has combined both quantitative and qualitative aspects. The latter have been essential in drawing meaningful conclusions about the process followed by the community itself in defence of their land rights. The research team visited Nicaragua twice. This included Managua, where the main government institutions are located, one visit to Bilwi (the capital of the Autonomous North Atlantic Region (RAAN) where the Awas Tingni community is located), and another visit to the community itself. The semi-structured interviews conducted with leaders and key community figures, as well

\footnotetext{
${ }^{3}$ Other authors have referred to these types of impacts and indirect as indirect, consequences, and symbolic effects (Rodríguez-Garavito and Rodríguez Franco, 2010: 18).

${ }^{4}$ It must be acknowledged that there is increasing interest in this topic. See a very interesting study conducted at American University, Washington (Martín and Rodríguez-Pinzón, 2013).

${ }^{5}$ The term transnational advocacy networks was coined by Keck and Sikkink (1998).
} 
as with other relevant actors in the case, were essential in obtaining the information required to reach our conclusions.

\section{THE DIFFICULT PROCESS OF IMPLEMENTING THE JUDGEMENT}

On August 31, 2001 the Inter-American Court of Human Rights made a historic decision concerning indigenous peoples' rights to their lands and natural resources.

The Awas Tingni case was not intended to end here, but to enter a new phase, namely the implementation stage. This has been deeply marred by difficulties, delays, and the lack of a clear political will on the part of the State to proceed with the demarcation and titling of the lands of the indigenous communities on the Atlantic Coast of Nicaragua (McLean Cornelio, 2005: 7). The problem is that the major actors in the cases themselves often fail to anticipate and prepare in advance for the implementation stage. The implementation of the judgment is such an important factor that it cannot be left to improvisation. As has been rightly emphasised, "specific mechanisms and additional resources are needed to strengthen the compliance policies of States, and the role of the very bodies in the Inter-American Human Rights System” (Martín Beristain, 2009: 119).

As stated in the Court's judgment, the State must, "adopt the legislative, administrative, and any other measures required to create an effective mechanism for delimitation, demarcation, and titling of the property of indigenous communities, in accordance with their customary law, values, customs and mores” (Inter-American Court of Human Rights, 2001: para. 164). In the specific case of the Awas Tingini community, the Court granted the State 15 months to "carry out the delimitation, demarcation, and titling of the corresponding lands of the members of the Awas Tingni Community... with full participation by the Community and taking into account its customary law, values, customs and mores” (Ibid). From the very beginning it was seen that the implementation stage of the judgment would be fraught with obstacles and difficulties. As recognised by the community's lawyer, it was not until five months after the judgment had been issued that the Government agreed to meet with the InterAmerican Commission on Human Rights and the community's representatives in order to take the first steps towards implementation (Anaya and Campbell, 2009: 143). In February 2002, representatives of the Government and of the Awas Tingni met in the offices of the Inter-American Commission in Washington for the Government to deliver a $\$ 30,000$ cheque for the legal costs and expenses (Inter-American Court of Human Rights, 2001: para. 169) incurred by the community members and their advisers during the domestic and international judicial proceedings. This was obviously one of the easiest steps to take, as it was merely a financial measure, while the implementation of the substantive aspects of the judgment would be much more complicated, as shall be seen below. 


\section{III.1. The Joint Commissions for the implementation of the Judgment}

At a meeting held at the Ministry of Foreign Affairs in Managua in April 2002, a decision was made to create two joint commissions to ensure the implementation of the Court's Judgment (Alvarado, 2007: 619). The membership of these commissions was quite diverse, as it was open to the participation of members of the Awas Tingni, their representatives and government delegates. The first of these Joint Commissions addressed compensation for immaterial damages suffered by the community. As specified by the Court in this regard, "the State must invest, as reparation for the immaterial damages, in the course of 12 months, the total sum of US\$ 50,000 (fifty thousand United States dollars) in works or services of collective interest for the benefit of the Awas Tingni Community, by common agreement with the Community and under the supervision of the Inter-American Commission" (Inter-American Court of Human Rights, 2001: para. 167). Despite some in-depth discussions taking place about monetary reparations, this issue was resolved with relative ease, and an agreement between the community and the Government was finally reached. The words of one of the major participants of these discussions are highly revealing:

\footnotetext{
"what the State tried to do with the \$50,000 reparations was to say that they wanted to put in latrines, a road ... things they had to do for any community, but which they had not actually done. They got to that point without the legal representative knowing and they said: 'we are going to do this', without the community knowing that they were talking about reparations. The State then said it already had an agreement with the community to use the $\$ 50,000 \ldots$ We said that was no good, it had to be agreed with the petitioners, the Inter-American Commission and the community. And so the hostel was proposed. Also some sewing machines for women. There were some problems in implementing these things, but finally they were, and it has had a largely positive impact on the community"6.
}

One of the most important aspects of the collective reparation measures ordered by the Inter-American Court is they are not to be confused with development policies that States have an obligation to carry out. As shown by James Anaya's statement, the original intention of the Government was to pass off the reparations ordered by the Inter-American Court as overall development policies. The role of the community's advisers and its leaders was again crucial in avoiding the confusion the government's strategy intended. In this sense, "the community's capacity for analysis and negotiation was a key factor in avoiding political manipulation and providing measures that were truly compensatory in nature" (Ibid). The most important part of these reparations was the construction of a hostel in Bilwi for 80 students, which was inaugurated on 28 February, 2003 (Alvarado, 2007: 619). This decision says a lot about the community and the value given to the education of the young Mayangna, who cannot continue their studies in the community and have to move to Bilwi. As noted by an elder of the Awas Tingni, "the community met and decided to do it, because the students needed accommodation”7.

\footnotetext{
${ }^{6}$ Interview with James Anaya in Martín Beristain (2009: 401).

${ }^{7}$ Unfortunately, Hurricane Felix, which struck the Atlantic Coast of Nicaragua on 4 September 2007, almost destroyed the entire hostel's roof. It has still not been rebuilt, although some students continue to use it.
} 
The second Joint Commission would face much greater challenges, as its objective was the planning and design of the process for the delimitation, demarcation and titling of the Awas Tingni territory. The most significant advances were in reaching a consensus on certain guiding principles for the delimitation, demarcation and titling process. These principles were: The State has sole responsibility for the process; the process should take into account indigenous customary law on patterns of community land use, and; the full participation of the representatives of the Awas Tingni in the process is to be respected. Despite this modest progress on the thorniest issue involving the Awas Tingni case, it must be recognised that this second Joint Commission did not meet the targets it had set itself. This, to a large extent, "led to a further escalation of illegal third party activities on Awas Tingni territory” (Alvarado, 2007: 620), one of the main problems that the community continues to face to this day.

\section{III.2. The adoption of provisional measures by the Inter-American Court}

Faced with this governmental impasse and the increased interference by third parties in the territory of the Awas Tingni, in July 2002 the community representatives requested that the Court adopt some provisional measures ${ }^{8}$. As noted by the representatives in their request, "there is a need for provisional measures to be adopted to maintain the status quo of the Community and to ensure compliance with the judgment of the Court... to avoid immediate and irreparable damage resulting from the current and continuous activities of third parties who have established themselves in the territory of the Community" ${ }^{\text {" }}$. In response to this request, on 6 September 2002 the Inter-American Court issued a resolution for provisional measures to be adopted. The Court's resolution required the State of Nicaragua to adopt, "without delay, whatever measures are necessary to protect the use and enjoyment of property of lands belonging to the Mayagna Awas Tingni Community, and of natural resources existing on those lands" ${ }^{10}$. In particular, the Court was concerned about the presence of third parties in the community's territory. That is why the Court required the state to take measures with a view to "avoiding immediate and irreparable damage resulting from the activities of third parties who have established themselves inside the territory of the Community or who exploit the natural resources that exist within it" ${ }^{11}$. Finally, the Court required the State "to investigate the facts set forth in the claim that gave rise to the current measures, so as to discover and punish those responsible" ${ }^{12}$. This shows how the Court tried to involve itself in the monitoring process for the implementation of the judgement adopted a year earlier. As shall be seen below, one of the most significant events with regard to the compliance with the Court's decision was the adoption of a specific legislative framework for the delimitation, demarcation and titling of indigenous lands

\footnotetext{
${ }^{8}$ Pursuant to Article 63.2 of the American Convention of Human Rights, "in cases of extreme gravity and urgency, and when necessary to avoid irreparable damage to persons, the Court shall adopt such provisional measures as it deems pertinent in matters it has under consideration".

${ }^{9}$ Order Of The Inter-American Court Of Human Rights Of September 6, 2002, Provisional Measures Requested By The Representatives Of The Victims With Respect To The Republic Of Nicaragua, Costa Rica, 2003.

${ }^{10}$ Ibid.

${ }^{11}$ Ibid.

${ }^{12}$ Ibid.
} 
on the Atlantic Coast of Nicaragua (Anaya and Campbell, 2009: 144). This had been an old demand of the civil society of the Atlantic Coast and indigenous peoples, and had been included among the measures ordered in the Inter-American Court of Human Rights’ judgment.

\section{III.3. Law 445 (2003)}

It has already been mentioned how, in the mid-1990s, spurred by the claim filed by the Awas Tingni before the Inter-American Commission and the pressures of the World Bank, the Nicaraguan Government began to seek a solution to the problem of the lack of a legislative framework to regulate the delimitation, demarcation and titling of indigenous territories. In addition, there was a broad mobilisation of civil society and the institutions of the Autonomous Regions of the Atlantic Coast, which culminated in a bill that was presented to the National Assembly in September 2000. Its aim was to regulate the communal property rights of the indigenous peoples of the Coast. This project did not have the approval of the Government, which had not favoured a comprehensive solution to the problem of the indigenous lands on the Caribbean Coast. A law that specifically dealt with the demarcation and titling of indigenous lands was finally adopted as a consequence of a specific set of "political circumstances and opportunities for the coastal population's demands at national level” (González and Figueroa, 2009: 332). It was within this difficult context "that the judgment of the InterAmerican Court on the Awas Tingni case came into play, as a key factor that led to a complete restructuring of the system of indigenous communal property on the Atlantic Coast" (Rodríguez-Piñero, 2004: 223) ${ }^{13}$. This restructuring came hand in hand with the adoption of the Law of Communal Property Regime of the Indigenous Peoples and Ethnic Communities of the Autonomous Regions of the Atlantic Coast of Nicaragua and Bocay, Coco, Indio and Maíz Rivers (Ley del Régimen de Propiedad Comunal de los Pueblos Indígenas y Comunidades Étnicas de las Regiones Autónomas de la Costa Atlántica de Nicaragua y de los Ríos Bocay, Coco, Indio y Maíz) in December 2002, also known as Law $445(2003)^{14}$. It must be acknowledged that the process involved in the debate and subsequent adoption of Law 445 was closely linked to the Court's judgement on the Awas Tingni case ${ }^{15}$, with this Law being one of its most important

\footnotetext{
${ }^{13}$ The political situation in Nicaragua at that time also helped facilitate the adoption of Law 445 (2003). As stated by Luis Rodríguez-Piñero (2004: 228-229), "the impeachment and subsequent imprisonment of former president Arnoldo Alemán under serious allegations of corruption” was also a determining factor, since "Alemán was the President of the National Assembly up to that point, and the main obstacle to a law that directly threatened his network of economic and clientelist interests in the Atlantic region”. In this new context, the Sandinista parliamentary group became one of the main bastions of support for the bill, a project that was finally sanctioned by the liberal government of President Bolaños in the light of the political pressure exerted by different political and social sectors.

${ }^{14}$ La Gaceta Diario Oficial, no. 16, 23 January 2003.

${ }^{15}$ As noted by someone with a deep knowledge of the hidden details that led to the adoption of the law 445 McLean Cornelio, 2004), "the Awas Tingni case played a key role in shaping the political situation that led to the approval of the new Law on Demarcation, Law 445 (2003) ... the Judgment of the Court was one of the weapons in the hands of the Atlantic Coast indigenous movement in pressing for the law to be adopted”.
} 
consequences (Open Society, 2011: 20) ${ }^{16}$. It is therefore not surprising that the content of the Law was clearly inspired by the parameters set by the judgment of the InterAmerican Court on the delimitation, demarcation and titling of indigenous territories (Wiggins, 2002: 18) ${ }^{17}$.

After acknowledging in the Preamble that "it is the ineludible commitment of the State of Nicaragua to respond to the claim for the titling of the lands and territories of the indigenous peoples and ethnic communities of the former Mosquitia”, Law 445 (2003) established as one of its basic objectives "to guarantee the indigenous peoples and ethnic communities the full recognition of communal property ownership rights, the use, administration and management of traditional lands and their natural resources, through the demarcation and titling of the same" 18 . Law 445 clearly recognised the collective ownership nature of the indigenous lands. As noted in Article 29, "the rights and ownership over communal land belong collectively to the indigenous and ethnic communities". The whole process of the demarcation and titling was based on a series of general principles and criteria established in the Law itself. ${ }^{19}$ These principles were as follows: the full participation of the indigenous people "through their traditional authorities" 20 ; "the will to focus and harmonise" the different parties involved in the demarcation and titling process ${ }^{21}$; the prevalence of the "historical and cultural possession exercised by the... community" to determine the area to be recognised ${ }^{22}$, and, finally, the search for peaceful solutions to any conflicts that may arise $\mathrm{a}^{23}$.

Another important aspect in the process of the demarcation and titling of indigenous lands on the Atlantic Coast is its institutionalisation, since Law 445 (2003) created two bodies that were to be key to the development of this process. These two bodies were the National Demarcation and Titling Commission (Comisión Nacional de Demarcación y Titulación (CONADETI) $)^{24}$, and the Intersectorial Commissions for Demarcation and Titling (Comisiones Intersectoriales de Demarcación y Titulación $(C I D T))^{25}$. In principle, the tasks of both bodies were clearly defined and differentiated.

\footnotetext{
${ }^{16}$ As noted by María Luisa Acosta, "Law 445 (2003) was the most effective outcome of the Judgment on the Awas Tingni case”. Interview conducted in Managua on 12 July 2011.

${ }^{17}$ In fact, Law 445 (2003) contains some quotations from the Judgment of the Inter-American Court. For example, when Article 44 of the Law lists the functions of the Demarcation and Titling Intersectorial Commissions, (Comisiones Intersectoriales de Demarcación y Titulación(CIDT)) it paraphrases Operative Paragraph No. 3 of the Court's Judgment (para. 173). As stated in Article 44.c, the function of the CIDT is to "create an effective mechanism for the delimitation, demarcation and titling of the property of indigenous communities, in accordance with customary law, values, uses and mores".

${ }^{18}$ Article 2.1.

${ }^{19}$ One of the most systematic studies of Law 445 (2003) is that by Lilliam Jarquín (2003: 6-18), who directly participated in its negotiation and discussion. See also Alfred-Cunningham (2011: 203-222).

${ }^{20}$ Article 40.a).

${ }^{21}$ Article 40.b).

${ }^{22}$ Article 40.c).

${ }^{23}$ Article 40.d).

${ }^{24}$ Article 41 of Law 445 created the CONADETI and its composition, while its functions are listed in Article 43.

25 Article 42 of Law 445 provides for 3 Inter-sectorial Committees: one in the Autonomous North Atlantic Region (Región Autónoma del Atlántico Norte (RAAN)), one in the Autonomous South Atlantic
} 
Whereas the CONADETI was to engage in "eminently political and coordination work", the Inter-sectorial Committees "were responsible for the technical aspects of demarcation on the ground” (Rodríguez-Piñero, 2004: 230).

The process of demarcation and titling was carried out in five stages, as required by the Law ${ }^{26}$ : the first stage was the submission of the request by one or more communities $^{27}$; this stage was to be followed by one involving the settlement of possible disputes with neighbouring communities or third parties ${ }^{28}$; once the conflicts had been settled, the measuring and marking out stage would begin ${ }^{29}$ which, once completed, would result in the titling stage $\mathrm{e}^{30}$. The last stage was to involve the title clearance in relation to the third parties located within them ${ }^{31}$.

Despite the progress brought by the adoption of Law 445 (2003) in modifying the indigenous land tenure system and further developing the autonomy in the Atlantic Coast of Nicaragua, both the legislative and institutional framework for the process of the demarcation and titling of indigenous lands had systemic deficiencies and internal obstacles that have been very difficult to overcome (Alvarado, 2007: 626). In addition to the strong political opposition by the central Government, there have been continuous delays in the process, a lack of technical training of the personnel carrying out their duties in both the CONADETI and the Intersectorial Committees, an absence of an adequate budget to carry out the work (Broegaard and Rivas, 2007: 56), and conflicting interests that the members have been, and continue to be, subject to ${ }^{32}$. James Anaya's comments regarding the progress resulting from the approval of Law 445 (2003) have been very revealing. In his qualified opinion:

\footnotetext{
"In general, the law is adequate, it is quite progressive ... The problems are lack of funding, the lack of technical training of the people who are there, and the politicisation of the institutions. When the parties that have won the elections change the people, continuity is lost. This has become part of the political game" (emphasis added) ${ }^{.33}$.
}

Ultimately, despite the significant steps that had been taken as part of the whole process involved in the Awas Tingni case, both the political context and the legal and institutional culture still present today in Nicaragua and the Atlantic Coast continue to pose a very strong structural barrier for the defence of the territorial rights of the indigenous communities.

\footnotetext{
Region (Región Autónoma del Atlántico Sur (RAAS)) and another in the basin of the Coco and Bocay Rivers (Cuenca de los Ríos Coco y Bocay). Their roles are contained in Article 44 of the Law.

${ }^{26}$ Article 45.

${ }^{27}$ The process of the request submission phase is described in Articles 46 to 51 of the Law.

${ }^{28}$ Articles 52 and 53.

${ }^{29}$ Articles 54 and 55.

${ }^{30}$ Articles 56 to 58.

${ }^{31}$ Article 59.

32 As noted by Sandra Brunneger (2007: 7), “CONADETI members are motivated by complex and interrelated political factors: party loyalty, loyalty / identification with a particular ethnic or mixed-race group, commercial links, relationships for influence, electoral convenience and personal ambition”.

${ }^{33}$ Interview with James Anaya, in Martín Beristain (2009: 156).
} 


\section{III.4. Titling request by the Awas Tingni community}

While the Awas Tingni community maintained the view that the obligation to demarcate and title their territory was independent from the adoption of Law 445 (2003), and that it emanated directly from the judgment of the Inter-American Court of Human Rights, the Nicaraguan State insisted that the community had to follow the procedures established by the Law for the demarcation and titling of their ancestral territory (Alvarado, 2007: 625). In view of this situation, the community decided to submit their titling request to the CIDT on 11 November 2003. Symbolically, this request was the first to be made under the new Law (Anaya and Campbell, 2009: 145). Pursuant to Article 46 of Law 445 (2003), the request submitted had to be accompanied by a fairly complete diagnosis of the main characteristics of the community ${ }^{34}$. With the consent of the community, this diagnosis was commissioned by the Government from a consortium of consultants including ALISTAR-Nicaragua, the Centre for Information and Documentation on the Atlantic Coast (Centro de Información y Documentación sobre la Costa Atlántica (CIDCA)), and the Central American University (UCA), which also had the collaboration of the Idaho State University. The study was funded by the World Bank Land Administration Project (Proyecto de Ordenamiento de la Propiedad del Banco Mundial (PRODEP), with the participation of members of the community. The Diagnosis of Tenure and Land Use of the Mayangna Awas Tingni Community (Diagnóstico de Tenencia y Uso de la Tierra de la Comunidad Mayangna de Awas Tingni) concluded that the territory claimed by the community "is part of the Mayangna' ancestral lands, over which the Mayangna had had control at least since the eighteenth century" 35 . One of the main conclusions of the study was that "the current Awas Tingni Community uses and knows all of the territory claimed" 36 . In addition, "in terms of the customary law recognised by the Inter-American Court, the community exercises and enjoys this right throughout the claimed area" ${ }^{37}$. In this sense, the Diagnosis estimated that the Awas Tingni "actively use nearly 125,000 hectares in all of their activities, especially for hunting..." "38. However, as the study concluded, "the current land claimed amounts to 94,394 hectares or $76 \%$ of the area used” 39 . Finally, with regard to conflicts with neighbouring communities, the study acknowledged that several Miskito communities claimed 41,000 hectares within the same area claimed by the Awas Tingni. However, "these communities were not originally from that area, but

\footnotetext{
${ }^{34}$ According to Article 46, the diagnosis of the community must contain the following information: the historical background of the community; their demographic, social, economic and cultural characteristics; their traditional forms of management, use and tenancy for the requested area; the name of the indigenous or ethnic communities and other entities or persons occupying land adjacent to the requested areas; and any possible conflicts that may arise between the community and the neighbouring communities or third parties.

${ }^{35}$ Diagnóstico de Tenencia y Uso de la Tierra de la Comunidad Mayangna de Awas Tingni (RAAN), ALISTAR-Nicaragua-CIDCA-UCA, Managua, Nicaragua, 13 October 2003, p. 5. It also stated in the Diagnosis that "secondary sources match the oral history of the community in order to prove the ancestral relationship between the Mayangna people and the territory claimed”, Ibid, p. 31.

${ }^{36}$ Ibid, p. 178.

${ }^{37}$ Ibid, p. 178.

${ }^{38}$ Ibid, p. 170.

${ }^{39}$ Ibid, p. 170.
} 
had been relocated to the north of the Wawa River by the Nicaraguan Agrarian Institute (IAN) in the $1970 \mathrm{~s}^{\prime 40}$.

Once the titling request had been submitted to the CIDT, under Law 445 (2003) the CIDT "must issue an opinion no later than thirty (30) days after receipt" ${ }^{41}$. This requirement was not met, since the request lay idle for more than a year without being revised. When the CIDT reviewed the request, it was sent to the CONADETI. This was another example of the absurdities and lack of technical training and financial resources to adequately perform their duties ${ }^{42}$ as, pursuant to Articles 19 and 52 of Law 445 (2003), any disputes between neighbouring communities that they had been unable to resolve $^{43}$, should have been settled by the relevant Regional Council (i.e. the Regional Council of the RAAN). This had been the case with the conflict between the Awas Tingni and the neighbouring Miskito communities. However, it was not until December 2004 that the CONADETI forwarded the titling request to the Commission on Demarcation of the Regional Council of the RAAN. Once again, this is a clear example of incompetence and continuous delays occurring. While Law 445 provides that the Regional Council should resolve the conflict "within a maximum period of three months"44, the conflict resolution stage did not begin until March 2005 and took almost two years to complete, until February 2007 (Anaya and Campbell, 2009: 145).

\section{III.5. Dispute settlement stage}

As we know, one of the most controversial aspects of the Awas Tingni case has been the territorial conflicts with the Miskito neighbouring communities, given the tense relationships that have historically existed between the Mayangna and Miskito peoples. The three neighbouring communities with problems of overlapping territorial claims were Francia Sirpi, Santa Clara and La Esperanza (collectively known as Tasba Raya). As mentioned earlier, the Diagnosis made in 2003 showed how these communities came to their present location after having been relocated there by the Nicaraguan Agrarian Institute (IAN) in the $1970 \mathrm{~s}^{45}$. These communities began to use increasingly larger areas and, to meet their growing needs, they began to demand a territorial space that went beyond the titles recognised by the IAN, thus entering the ancestral lands of the Awas Tingni ${ }^{46}$. As James Anaya and Maia Campbell (2009: 147) rightly pointed out, the Nicaraguan government officials repeatedly argued that the

\footnotetext{
40 Ibid, p. 6.

${ }^{41}$ Articles 47 and 48.

42 As bitterly acknowledged by Anaya and Maia Campbell (2009: 146), both the CONADETI and the CIDT lacked an operational budget, sufficient personnel and permanent headquarters both in 2004 and 2005. For its part, the Demarcation Commission of the Regional Council of the RAAN did not receive funds to address the conflict resolution stage until 2005.

43 As stated in Article 19 of Law 445 (2003), "the Autonomous Regional Council, through the Demarcation Commission, shall be responsible for resolving any community border disputes that the communities themselves have not been able to resolve in a direct fashion, if all the options have been exhausted by the territorial authorities".

${ }^{44}$ Article 53.

${ }^{45}$ Diagnóstico de Tenencia y Uso de la Tierra..., op. cit., p. 6.

46 These territorial claims are documented in Hale and Gurdián (1998).
} 
conflict between the Awas Tingni and their neighbouring communities was the main reason for the lands not having been titled to the Awas Tingni, in an attempt to divert attention from the lack of institutional capacity and political will to make significant progress in the demarcation and titling process.

In March 2005 after countless delays, the second stage provided for under Law 445 (2003) began. This was the dispute settlement stage, which entailed the demarcation and titling of the indigenous territories ${ }^{47}$. As established by the Law, the Demarcation Commission of the Regional Council of the RAAN convened several meetings between the Awas Tingni and the Tasba Raya communities in an attempt to reach a solution to the problem of territorial overlap of an area of 41,000 hectares. However, by the end of 2006 it was clear that these mediation attempts were doomed to failure. In the absence of an amicable solution between the communities in dispute, the Demarcation Commission of the Regional Council of the RAAN issued a resolution ${ }^{48}$ which resolved the conflict between the Awas Tingni community and its three neighbouring communities. By virtue of this resolution, of the 41,000 hectares in dispute, 20,000 hectares were granted to the Awas Tingni and the remaining 21,000 hectares were divided equally between the three Miskito communities, that is, 7,000 hectares were allocated to the Sirpi Francia community, 7,000 hectares to the Santa Clara community, and 7,000 hectares to the community of La Esperanza. ${ }^{49}$ Finally, the Regional Council rendered its own decision in February $2007^{50}$ to end the dispute settlement stage, as provided for in Article 21 of Law 445 (2003), by simply ratifying the decision taken by the Demarcation Commission.

The end of the dispute settlement stage in early 2007 happened to coincide with Daniel Ortega becoming the President of the Republic. He had won the elections in coalition with the main indigenous party of the Atlantic Coast, YATAMA. As we shall

\footnotetext{
${ }^{47}$ Chapter 9 of Law 445 (2003), Articles 52 and 53.

${ }^{48}$ Resolution No. C.D / C0-02-10-07. The Demarcation Commission also established that the hectares "should be counted from the Wawa River southwards in the overlapping area shown in the Awas Tingni Diagnosis, except for the ancient and sacred sites of the Awas Tingni, such as Tuburús”.

49 This transfer of 21,000 hectares has never been considered to be fair by the Awas Tingni. As noted in the community meeting held in Awas Tingni on 8 July, 2011, "the transfer of 21,000 hectares to neighbouring communities was an imposed requirement; the community did not want it, but they had no choice. But the community still considers the territory as being theirs, we have not forfeited this right (there are cemeteries, ancestral community, sacred sites there...)”.

50 "Ratification of the Resolution of the Commission of Territorial Demarcation and the Autonomous Regional Council of the North Atlantic resolving the border conflict between the indigenous Awas Tingni Community and the Indigenous Communities of Francia Sirpi, Santa Clara and La Esperanza Territory of Tasba Raya”, Resolution No. 26-14-02-2007, adopted in Bilwi on 14 February 2007. In August 2008, the Regional Council of the RAAN resolved another territorial conflict between the Awas Tingni and the socalled Ten Communities (Diez Communidades). In this case, the Council did not change the territorial area that had been recognised as belonging to the Awas Tingni as in its previous Resolution of 14 February 2007, that is, 73,394 hectares. For more on this, see "Ratificación de la disposición administrativa no. 45-25-06-2008 sobre el conflicto territorial entre el territorio de la Diez Comunidades y la Comunidad Sumo-Mayngna de Awas Tingni', Resolution No. 63-11-08-2008”, adopted in Bilwi on 11 August 2008.
} 
see below, this event provided a strong impetus to the process of demarcation and titling of indigenous territories on the Atlantic Coast of Nicaragua.

\section{III.6. The agreement between the Sandinista National Liberation Front (el Frente Sandinista de Liberación Nacional (FLSN)) and YATAMA}

With a view to participating in the Presidential elections in November 2006, at the beginning of that year an agreement was initiated between Daniel Ortega's FSLN and the main indigenous party from the Atlantic Coast, YATAMA ${ }^{51}$. As a result, a change started to be seen in the traditional disdain with which the political class and the liberal Governments that had been in power since the 1990s had treated the demands from the indigenous peoples on the Atlantic Coast. One of the key points of the Commitment Agreement between the FSLN and YATAMA signed in Bilwi in May 2006 was specifically to support the process of demarcation and titling of indigenous territories. As stated in the first point of the Agreement, one of the commitments to be implemented both by the Regional Autonomous Governments and by the National Government was "the political and economic support of the institutions responsible for the process of demarcation and titling of indigenous and Afro-descendent territories based on Law 445 and the criteria included in the judgment of the Inter-American Court of Human Rights on the Case of the Awas Tingni v. Nicaragua, which stated that the demarcation and titling of indigenous lands should be according to customary law, values, customs and mores of indigenous communities"52. Another important point of the Agreement had to do with the protection of indigenous peoples' natural resources. As provided in Paragraph 7 of the Agreement, "an effective and sustained effort will be urgently promoted to contain the agricultural frontier, the indiscriminate cutting of forests and the plundering of natural resources in the autonomous regions...”. As we can see, this Agreement was a firm commitment to the demarcation and titling of indigenous territories on the Atlantic Coast of Nicaragua, following the parameters established by the Judgment of the Inter-American Court of Human Rights in the Awas

\footnotetext{
51 The acronym YATAMA stands for Yapti Tasba Masraka Nanih Asla Takanka. Although fundamentally of Miskito origin, YATAMA has sought to represent all of the indigenous peoples of the Atlantic Coast. The relationship between the Mayangna indigenous people and YATAMA has been ambivalent, as they do not feel totally represented by that political party. This view was corroborated by one of the local consultants, who stressed that "YATAMA does not represent the Awas Tingni community...; some Mayangna leaders have joined it, but it does not represent the Mayangna communities. They are political agents, not community leaders.' The members of the Awas Tingni not only do not feel represented by YATAMA, but sometimes have come to see this political party as a threat. As recognised by a prominent member of the Awas Tingni community, 'YATAMA was against us at first, but eventually the Government gave their support”. According to Miguel González and Dolores Figueroa (2009: 338), the situation on the Atlantic Coast is very complex and has multiple problems, so YATAMA cannot be considered to be the sole legitimate voice for regional demands.

${ }^{52}$ Commitment Agreement between the FSLN and YATAMA, made in Bilwi on 2 May 2006 (a document in the possession of the authors of this study). The first point of the Agreement also refers to "the full participation of indigenous peoples as actors and beneficiaries' of the process of the demarcation and titling of indigenous territories”. In addition, it specifies that support for the process of demarcation and titling "implies the revival of CONADETI and the CIDTs, the design and scheduling of the action plans, the allocation of financial and technical resources, the development of ethno-maps designed by the communities, among others, which result in the delivery of communal titles to all communities involved”.
} 
Tingni case, which was expressly cited in the Agreement we have just analysed. In the words of Leonardo Alvarado, a lawyer at the University of Arizona who was part of James Anaya's team in the implementation process of the Court's judgment, the Agreement between YATAMA and the FSLN can be conceived "as a mechanism for incorporating international human rights standards on indigenous peoples, as it cites the Awas Tingni and YATAMA decisions as reference points for carrying out the provisions of the agreement” (Alvarado, 2007: 641) ${ }^{53}$.

The victory of this electoral coalition and its coming to power in January 2007 contributed to a fundamental change in Nicaragua's political and institutional scenario, especially with regard to the demarcation and titling process of indigenous territories on the Atlantic Coast, which received a significant boost (Open Society, 2011: 73) ${ }^{54}$. The fact that the indigenous institutions linked to YATAMA ${ }^{55}$ became part of the Government brought with it an unprecedented outlook to Nicaraguan politics that was felt in most of the policies related to indigenous claims ${ }^{56}$. As a prominent member of YATAMA noted, the assessment of the Agreement with the FSLN in general was "positive; it is not easy to implement, but there is progress. It is an opportunity to realise our aspirations and rights" 57 .

\footnotetext{
${ }^{53}$ On 23 June 2005 the Inter-American Court of Human Rights again ruled against the State of Nicaragua for maintaining an electoral law that failed to place the candidates of parties with indigenous roots (such as YATAMA) on an equal footing with the rest. Specifically, the Court considered the decision of the Higher Electoral Council to exclude YATAMA candidates for mayors, deputy mayors and councillors from participating in the municipal elections held on 5 November, 2000 in the RAAN and the RAAS, to be a violation of the American Convention on Human Rights. Therefore, the Court ordered Nicaragua to reform Electoral Law 331 (2000) and "adopt, within a reasonable time, the necessary measures to ensure that the members of the indigenous and ethnic communities may participate in the electoral processes effectively and taking into account their traditions, practices and customs", in the Inter-American Court of Human Rights Case of YATAMA v. Nicaragua Judgment of June 23, 2005, para. 259.

${ }^{54}$ As noted by one of members of the CONADETI, the Agreement between the FSLN and YATAMA has been "essential in the demarcation and titling process of indigenous lands on the Atlantic Coast". A very similar view was held by one of the leaders of the Nicaraguan Government's indigenous policies, for whom "the core of the Agreement between the FSLN and YATAMA is the land ... The Government has strongly insisted on this issue".

${ }^{55}$ This was another of the commitments of the Agreement between the FSLN and YATAMA. As stated in Paragraph 14.4 of the Agreement, "the alliance of these forces will ensure that ethnic pluralism, as a principle of the Nicaraguan nation, is reflected in the different branches of government and autonomous, decentralised bodies at the national level. These go beyond publicly-elected bodies, and the central Government cabinet described above, such as the Supreme Court, the Higher Electoral Council, the Special Attorney for Indigenous Peoples, and the Public Prosecutor, among others. In this regard, the allies shall promote and support the members of indigenous peoples and Afro-descendant communities to be included in these bodies".

${ }^{56}$ The significant increase in the presence of indigenous people in institutions is one of the most important results of the successive agreements (2006 and 2011) between the FSLN and YATAMA.

${ }^{57}$ The Commission of Ethnic Affairs, Autonomous Regimes and Indigenous Communities of the National Assembly of Nicaragua has fostered the adoption of various laws and measures to promote the rights of indigenous peoples. In this regard, of note is the ratification by Nicaragua in August 2010 of ILO Convention 169 on Indigenous and Tribal Peoples in Independent Countries.
} 


\section{III.7. Measuring and marking out stage}

As stipulated in Law 445 (2003), once the dispute settlement stage was completed, the stage for the measuring and marking out of the territory of the indigenous communities territory was due to start ${ }^{58}$. The Inter-sectorial Demarcation and Titling Commission (CIDT) had up to 12 months to carry out this highly technical work $^{59}$. The State was required to provide the necessary resources for this task to correctly conducted, "without prejudice to the communities being able to carry it out using their own resources and/or external support" ${ }^{\text {60 }}$. This task was conducted without any major problems in relation to the territory of the Awas Tingni, and was undoubtedly helped by the new political and institutional climate prevailing in Managua ${ }^{61}$.

\section{III.8. Titling stage ${ }^{62}$}

Once the work of measuring and marking out the indigenous territory was successfully completed, it was time to issue the appropriate title deed and register it in the Public Real-Estate Record Office. Pursuant to Law 445 (2003), it was the CONADETI which, following the measuring and marking out procedures, was required to issue the corresponding title deed within 45 days $^{63}$. In the case of the Awas Tingni, the CONADETI issued the communal title deed ${ }^{64}$ to the AMASAU territory (Awas Tingni Mayangnina Sauni Umani $)^{65}$ on 13 December, 2008. This date went down in the community's history thereafter.

\footnotetext{
${ }^{58}$ Chapter 10, Measuring and Marking out (Medición y Amojonamiento), Articles 54 and 55.

${ }^{59}$ Article 54.

${ }^{60}$ Article 55. In addition, as stipulated by this Article, "the Demarcation and Titling National Commission (CONADETI) shall submit a General Plan for Measuring, Demarcation and Titling to the President of the Republic. The Plan will contain a budget and it must be included in the General Budget of the Republic as a priority and financed according to the annual breakdown" (emphasis added).

${ }^{61}$ The feeling that prevails among the members of the Awas Tingni community is that the coming to Government of Daniel Ortega with the support of YATAMA was an essential factor in the progress of their territorial claims. As noted by one of the members of the community, "after the Judgment of the Court it has not been easy ...; we knocked on President Bolaños' door ...; President Daniel Ortega then came to office, and that was when we got the title".

${ }^{62}$ Chapter 11, Titling Stage (Etapa de Titulación), Articles 56 to 58.

${ }^{63}$ Article 56.

${ }^{64}$ Communal Title Deed No. 007-13-12-2008, granted in Bilwi on 13 December, 2008. See the title in Annex III of this book. It is worth noting that that in the session in which the CONADETI elected its Management Board and issued the communal title deed to the Awas Tingni community, the bench of the Liberal Constitutionalist Party (PLC) left the plenary session. This is a sure sign that there are still some political sectors that do not willingly accept the advances in the process of demarcation and titling of indigenous territories on the Atlantic Coast.

${ }^{65}$ As stated in the communal title deed, the AMASAU territory is comprised of two land units: 1) "Tapa Burus Sau U Pa Umani Di Dahwa Pa (Tuburus), a sacred site for the Awas Tingni. It was established that the Wawa River was for common use. Free access was provided to the referred sacred area (Tuburus) through Tapam Busna to the confluence or union of the Wiruk and Kuru Was rivers, both of which give rise to the Wawa River"; 2) "Where the settlement of the Mayangna indigenous community of Awas Tingni and the sacred sites of Asang Nuhni Sau U Pa Umani, Wakumbaih Sau U Pa Umani” are located.
} 
The first aspect to be emphasised about the communal title deed to the AMASU territory is that the CONADETI encompassed it within the "inescapable historical commitment"66 of the State of Nicaragua and the Government of Reconciliation and National Unity ${ }^{67}$ to indigenous peoples. From a symbolic point of view, it is very important that reference was made to this historic commitment of the State to indigenous peoples and also that it was considered to be "unavoidable", given the conditions of exclusion and marginalisation in which these communities have lived throughout history ${ }^{68}$.

Another important dimension of the communal title deed to the AMASAU territory issued by the CONADETI is that it explicitly referred to the judgment of the Inter-American Court of Human Rights on the Awas Tingni case. The CONADETI recognised that the titling to the AMASAU land was simply a measure that Nicaragua had to adopt "pursuant to the judgment issued on 31 August, 2001 by the Honourable Inter-American Court of Human Rights"69. This was ultimately an "act of justice intended to claim and revitalise the full recognition of the historic right to communal property for the demarcation and titling of the ancestral land of the indigenous people of the AMASAU Territory" ${ }^{70}$.

Finally, a striking aspect in the communal title deed of the Awas Tingni is that the legal grounds used to argue the relevance for that title to be issued included a reference to the United Nations Declaration on the Rights of Indigenous Peoples adopted by the United Nations General Assembly on 13 September $2007^{71}$, in particular, to the provisions concerning the right of indigenous peoples to their lands, territories and resources ${ }^{72}$. This certainly may contribute to giving greater legitimacy and an increasing legal value to the Declaration.

\footnotetext{
${ }^{66}$ Recital IV of the Communal Title Deed.

${ }^{67}$ This was the name of the new Government established by Daniel Ortega in January 2007.

${ }^{68}$ It is important to stress that the United Nations Declaration on the Rights of Indigenous Peoples, adopted by the United Nations General Assembly in its resolution 61/295, on 13 September 2007, also makes an explicit reference to the question of the historical injustices suffered by indigenous peoples and how this has affected their right to development and their right to lands, territories and resources. In the Preamble to the Declaration the General Assembly it states that it is "concerned that indigenous peoples have suffered from historic injustices as a result of, inter alia, their colonisation and dispossession of their lands, territories and resources, thus preventing them from exercising, in particular, their right to development in accordance with their own needs and interests” (para. 6). An analysis of this controversial issue can be found in Gómez Isa (2011: 265-300).

${ }^{69}$ Recital IV of the Communal Title Deed.

${ }^{70}$ Ibid.

${ }^{71}$ Nicaragua's National Assembly ratified the United Nations Declaration on the Rights of Indigenous Peoples on 11 March 2008. This was another result of YATAMA being in the Government from 2007 onwards.

${ }^{72}$ Recital III of the Communal Title Deed. It expressly refers to Article 26 of the Declaration, which reads as follows: 1. "Indigenous peoples have the right to the lands, territories and resources which they have traditionally owned, occupied or otherwise used or acquired"; 2. "Indigenous peoples have the right to own, use, develop and control the lands, territories and resources that they possess by reason of traditional ownership or other traditional occupation or use, as well as those which they have otherwise acquired'; 3. 'States shall give legal recognition and protection to these lands, territories and resources. Such
} 
Finally, following the provisions of Article 57 of Law 445 (2003), the CONADETI "requests that the Public Registrar at the Public Real Estate Record Office of the Autonomous Region of the North Atlantic urgently register the Communal Title Deed to the AMASAU Territory without cost to the beneficiaries". This registration took place on 13 December 2008, and marked the end of the titling stage.

\section{III.9. Title clearance stage}

The fifth and final stage in the process of the demarcation and titling of indigenous territories under Law 445 (2003) was the title clearance stage. Pursuant to Article 59 of the Law, "each of the communities, once they have obtained their title deed, may commence, with the technical and material support from the Rural Lands Titling Office (OTR), the title clearance stage, in relation to third parties occupying their lands"73. Title clearance was intended to identify and characterise the presence of third parties within indigenous territories in an attempt to reach a solution that was compatible with the exercise of the territorial rights by indigenous peoples. This required specifying their location, how they came to occupy those areas, documents that support their occupation, their activities and what impact these activities had on the natural resources in these territories. The truth was that "title clearance ... is crucial to provide effective protection to indigenous peoples... since the invasion of third parties directly affects the use and enjoyment of their collective lands” (Acosta, 2010: 13).

This is one of the most serious problems currently facing the Awas Tingni for a number of reasons, namely the accelerated colonisation process experienced in their territory in recent years caused by the settlement of war veterans from the 1980s war in the area with the support of the Government ${ }^{74}$; the unstoppable expansion of the agricultural frontier; and the unbridled race for the exploitation of valuable natural resources such as timber and minerals.

Once the Communal Title Deed to the AMASAU Territory had been issued and registered, on 8 July 2009 the Awas Tingni made a request for the title clearance stage of its territory to start. This request fell on deaf ears ${ }^{75}$, as the title clearance process was once again hampered by the lack of coordination between the institutions ${ }^{76}$, and the

recognition shall be conducted with due respect to the customs, traditions and land tenure systems of the indigenous peoples concerned”.

${ }^{73}$ Article 3 of Law 445 defines Third Parties (Terceros) as "natural or juridical persons, other than the communities alleging property rights within a communal land or an indigenous territory”. The OTR has been replaced by the so called Intendencia de la Propiedad, which has now assumed its functions. See “Restablecimiento y Desconcentración de la Intendencia de la Propiedad”, Decree No. 130-2004, La Gaceta Diario Oficial, No. 234, 1 December 2004.

${ }^{74}$ This is a politically and socially very complex issue, which, more than 20 years after the end of the war in Nicaragua, continues to generate much controversy (Abu-Lughod, 2000: 32-62).

75 The Awas Tingni has made five other requests for the opening of the Title Clearance stage of the AMASAU Territory. New requests were filed on 7 September 2009, on 23 October 2009, on 19 March 2010, on 1 June 2010 and the last on 24 October 2011.

${ }^{76}$ The CONADETI Management Board published a Manual of Procedure for the Title Clearance Stage (23 February 2008), but, in addition to being confusing as to the responsibilities of each institution, "it 
more than obvious limitation of economic resources ${ }^{77}$. As a result of successive title clearance requests by the Awas Tingni community, several reports were issued on the characterisation of the third parties within the AMASAU Territory ${ }^{78}$. While the CONADETI publicly committed itself to completing the title clearance process of all indigenous territories that fell under Law 445 throughout 2011, this has not involved significant actions by the institutions that have to carry out the title clearance (Comité Ejecutivo de la CONADETI, 2009) ${ }^{79}$.

Given the lack of a reaction from the institutions responsible for the title clearance, the community of Awas Tingni and the AMASAU Territorial Government, with the support of international cooperation and the Association of Indigenous Councils of Cauca (ACIN), in July 2011 started a report on the characterisation of third parties in the AMASAU Territory, promoting the necessary inter-institutional collaboration $^{80}$. This report was issued in May $2012^{81}$ and became the basis for the title clearance process to be carried out. This should once and for all complete the process of demarcation and titling of the AMASAU Territory. Its findings are quite worrying in relation to the colonisation of the community's territory. As noted in the report, "the advance of the settlement processes in the AMASAU Territory and the devastation of natural resources are extremely fast and uncontrollable; ... the settlement process is continuous and is increasing at a rapid pace with new migrants" ${ }^{82}$. This is a very telling fact about the increased presence of third parties in the AMASAU Territory. The 43 families and others in the Awas Tingni community's territory noted in the Diagnosis of

turns the title clearance stage into a bureaucratic and expensive procedure, more complex than necessary, contradicting the provisions of Article 59 of Law 445” (Acosta, 2010: 15).

77 The CONADETI itself has acknowledged that "it does not have the necessary materials, tools, equipment and means of mobilisation necessary to carry out the activities of the demarcation and titling process”, in Comité Ejecutivo de la CONADETI (2009: 13).

${ }^{78}$ Informe narrativo sobre los daños ambientales ocasionados por la presencia de colonos y/o terceros en las tierras de la comunidad indígena de Awas Tingni, MAGFOR-MARENA-INAFOR y Policía Nacional, May, 2010; Informe sobre la situación de avance de la frontera agrícola en los territorios Wangki Twi, Li Auhbra y AMASAU con jurisdicción en el municipio de Waspám, RAAN, prepared by the Permanent Special Committee on the Demand and Control of the Advancement of the Agricultural Boundary, May 2011.

${ }^{79}$ Evelyn Taylor, Member of the National Assembly, Deputy Head of the Real Estate Registry (PGR) and member of the CONADETI, openly admitted to us that the title clearance process is proving to be much more complicated than originally planned, and has not advanced as far as it should. In her opinion, it is not a problem of a lack of political will, but technical complications and the division and corruption within the indigenous communities themselves (Interview with Evelyn Taylor, held in Managua on 26 January 2012).

${ }^{80}$ The report was prepared by the CONADETI and CIDT, the delegate of the Ministry of Interior, the Regional Council, the Attorney General's Office (PGR), the Agriculture and Forestry Ministry (MAGFOR), the National Forestry Institute (INAFOR), the Ministry of Environment and Natural Resources (MARENA), the National Police and the Army of Nicaragua.

${ }^{81}$ Caracterización Jurídica y Social de Terceros en el Territorio Ancestral de la Comunidad Mayangna de Awas Tingni-AwasTingni Mayangnina Sauni Umani (AMASAU), ALMACIGA-Asociación de Cabildos del Norte del Cauca (ACIN)-Agencia Española de Cooperación Internacional y Desarrollo (AECID), May 2012.

${ }^{82}$ Ibid, p. 68. 
Tenure and Land Use drafted in $2003^{83}$ have increased to 424 families (1,916 people) in the current report. As noted with great concern in the report of 2012, this emphasises that "after the Diagnosis the number of settlers in the territory multiplied alarmingly" 84 . This means that, in practice, the claims of occupation by third parties in the AMASAU Territory extend to 67,375 hectares, that is, nothing more and nothing less than $91 \%$ of the territory of the Awas Tingni ${ }^{85}$. This situation led to the report's rather pessimistic conclusion:

"It is paradoxical that an indigenous community that has been internationally recognised for having prevailed in a lawsuit before the Inter-American Court of Human Rights against the State of Nicaragua for the recognition of their ancestral territorial rights, which used the Judgment issued in its favour to have a special law created for demarcation and titling for indigenous peoples of the Atlantic Coast (Law 445), and obtained a title with the implementation of this law, is facing the threat of the usurpation of $91 \%$ of their territory, all this under a government whose main indigenous peoples policy is the restoration of rights" ${ }^{86}$.

Faced with a situation which can only be described as a genuine emergency, on 28 May 2012 the President of the AMASAU Territorial Government sent a letter to the President of the Republic in which, in addition to enclosing a copy of the report on the legal and social characterisation of third parties in the territory of the Awas Tingni, he asked for "the immediate cessation of land usurpation in the AMASAU territory" and the full completion of the title clearance of the territory ${ }^{87}$.

As can be seen, the title clearance phase was tremendously complex and may strongly affect the whole of the process of the demarcation and titling of the AMASAU Territory. In fact, this is what has happened in the whole territory of the Moskitia, not only in relation to the AMASAU territory. The absolute lack of title clearance is paving the way to the invasion of the territories by settlers through violence, displacement and destruction of indigenous property ${ }^{88}$.

\footnotetext{
${ }^{83}$ Diagnóstico de Tenencia y Uso de la Tierra de la Comunidad Mayangna de Awas Tingni..., op. cit., p. 171.

${ }^{84}$ Caracterización Jurídica y Social de Terceros en el Territorio Ancestral de la Comunidad Mayangna de Awas Tingni..., op. cit., p. 68. In fact, over the last 5 years the settlement process has rapidly increased. As stated in the report being discussed, $62 \%$ of third parties have settled there in the last 5 years. This is due to several reasons: first, Hurricane Felix in September 2007, 'after which the prohibition on timber resources and the requirements for forest use were relaxed'; also, this acceleration has to do with "the government statement of 30 June, 2010, whereby there would be no eviction of third parties from the indigenous territories of the Atlantic Coast"; Finally, "poverty and lack of land to work are the main reasons of land occupation in the AMASAU territory”, Ibid, p. 70.

${ }^{85}$ Ibid, p. 69.

${ }^{86}$ Ibid, p. 69.

${ }^{87}$ Letter signed by Levito Jhonatan Mcklean, Audiño Nelson Demetrio and Barrington Salomon, 'Referencia: Acciones Inmediatas y Solicitud de Saneamiento Territorio AMASAU', Awas Tingni, RAAN, 28 May 2012 (document in the possession of the author of this study).

${ }^{88}$ Yapti Tasba Masraka Nanih Aslatakanka Yatama, Declaración de la Asamblea General Extraordinaria de los Pueblos Indígenas y Afrodescendientes de la Moskitia Nicaragüense "Comandante Mario Leman Muller”, Bilwi, 28 February 2016.
} 


\section{CONCLUSIONS}

1. The first conclusion has to do with the enormous importance that support has in the defence of a highly vulnerable group, such as indigenous peoples. On this occasion vulnerability was much greater given the degree of isolation and abandonment in which the Awas Tingni lived and their poverty levels. It was essential for the relationship that the team of lawyers had with the community to go beyond the traditional lawyer-client relationship. An indigenous community such as this was not just another client, it was a very special client that needed guidance and support, not only during the legal process that led to the 2001 Judgment, but also in the process of the implementation of the judgment. The team of lawyers led by James Anaya adjourned its work in Awas Tingni in December 2008, when the community was awarded the title to their ancestral lands and that title was registered. After the interviews we had with prominent members of the community, we detected a general sense of abandonment since, despite the title having been granted, the full implementation of the Judgment remains somewhat unfulfilled. The stage related to the title clearance of the community's territory still remains to be completed. The territory is still to this day invaded by settlers, illegal loggers, etc.. And the community does not have specialised legal advice that is accepted by all of them and provides them with protection against these continuing attacks on their ancestral rights.

2. Another lesson we have learned during our research is related to the importance of the processes, not just the results. How a particular result is reached is as important as the result itself. Because of this, our methodology has consistently sought to unravel the various key aspects in the process, the main actors, its dynamics, and its structural obstacles. A crucial element is that the process itself has to be conceived as a strategy for enabling and empowerment. The process that led to the legal victory in 2001 has been an essential tool for precisely this kind of enabling and empowerment. Most of the people we interviewed told us that, while before the case they had very vague notions of what human rights were, today they have more specific knowledge. But it is not only a question of knowledge; they also have the belief that, despite being indigenous people who have been left out of Nicaragua's history and institutions, they do have rights, and these rights have been recognised by none other than the InterAmerican Court of Human Rights, a genuine human rights court. The case and the process undergone by the community and their support team involved a significant degree of empowerment.

3. Another important aspect to consider is that the implementation process of the decisions of international courts rests largely on internal elements and factors. In this sense, as has been shown in this study, the political situation in Nicaragua in the early 2000s, with the return of the Sandinista National Liberation Front (FSLN) to the political scene, marked a before and after in the implementation process of the Awas Tingni judgment, something that had not been included in the priorities of neoliberal Governments. Another factor to take into account is the emergence of YATAMA, the indigenous party of the Atlantic Coast, as an actor on the national, and not only on the Atlantic Coast stage. The alliance between YATAMA and the FSLN in 2006, in which 
express reference was made to the implementation of the Awas Tingni judgment, was instrumental to its subsequent implementation. Daniel Ortega's (FSLN) coming to power in 2007 definitely unclogged some of the seemingly immovable obstacles in order to allow the process of demarcation, delimitation and titling of indigenous territories to be carried out.

4. The traditional evils of the Nicaraguan political system also affected the implementation process of the Awas Tingni judgment. Factors such as endemic corruption, the historical exclusion of the Atlantic Coast from national politics, the absence of a genuine rule of law and the weaknesses of the Awas Tingni community in defending their territorial rights, made the implementation process fraught with pitfalls and difficulties.

5. Another aspect that has become clear after our thorough investigation is that the mechanisms that the Inter-American Human Rights System has established for the implementation of its decisions is clearly improvable, to put it mildly. The InterAmerican Court has no specific effective mechanisms in place to accompany the implementation process of its decisions. There has been some progress, such as implementation hearings held before the Court itself, but there is still a long way to go, as acknowledged by both the Court and the General Assembly of the Organisation of American States, the political body which oversees the Inter-American System.

6. Finally, it must be acknowledged that the decision of the Inter-American Court of Human Rights in the Case of the Awas Tingni Community against Nicaragua (August 2001) has set a very promising precedent for the evolution of the right of indigenous peoples to their lands and natural resources in the international legal landscape. The interpretation given by the Court of the right to property in this landmark case has been a real challenge to the traditional concept of property rights contained in the most relevant international human rights instruments. In addition, this innovative and courageous jurisprudence has been followed and furthered by the InterAmerican Court in other cases where indigenous communities were also involved in the defence of their ancestral territories. The most significant cases are Yakye Axa, Moiwana, Saramaka, Sawhoyamaxa, Xákmok Kásek, and Sarayaku, among others. The Court followed what it called an 'evolutionary' interpretation method, opening the door to the use of regulatory developments on human rights produced in other contexts outside that of the Inter-American System. This enabled the Court to overcome purely formalistic criteria in its interpretation of the meaning, nature and scope of the right of indigenous peoples to the ownership of their lands and natural resources. Although Article 21 of the American Convention on Human Rights (1969) ${ }^{89}$ does not explicitly refer to the indigenous peoples' right to collective property, the interpretation offered by the Court is that that provision includes not only the traditional and orthodox conception of property as an individual right, but that it must also protect the communal property of indigenous peoples as defined by their own custom and usage. As a result of this new

\footnotetext{
${ }^{89}$ Article 21.1 of the American Convention on Human Rights states that "everyone has the right to the use and enjoyment of his property. The law may subordinate such use and enjoyment to the interest of society”.
} 
interpretation, the Inter-American Court concluded that the State of Nicaragua had violated the right to property of the Awas Tingni, since concessions had been made to a logging company without their consent and by failing to complete the demarcation, titling and registration of the community's territory as demanded both by the Nicaraguan Constitution of 1987 and the Statute of Autonomy of the North Atlantic Autonomous Region (RAAN, 1987).

The second innovative aspect of the Court's decision has to do with the predominantly collective dimension given to the property rights of indigenous peoples, something that clashes with the classical interpretation of human rights in the Western world. Helped by the testimonies of leaders of the Awas Tingni community and experts in the rights of indigenous peoples in the public hearing held at the seat of the Court in San José, Costa Rica, the highest Court of the Americas on issues related to human rights concluded that 'among indigenous peoples there is a communitarian tradition regarding a communal form of collective ownership of land, in the sense that ownership of land is not cantered on an individual but on the group and community' (para. 149). In the same vein, the Court held that 'the close ties of indigenous people with the land must be recognised and understood as the fundamental basis of their cultures, their spiritual life, their integrity and their economic survival' (para. 149), emphasising the cultural and spiritual significance the land has in indigenous worldviews. Another important point in the pronouncement by the Court was to do with the ultimate basis for the indigenous right to property. For the Court, the basis for the right to property does not come from recognition by the State, but is grounded on the customary practices of indigenous communities. In the words of the Court, "as a product of custom, possession of land should suffice for communities lacking real title to property of the land to obtain official recognition of that property and the subsequent registration” (para. 151).

Therefore, the Court ruled against the State of Nicaragua for violating the property rights of the Awas Tingni and, consequently, the State was obliged to delimit, demarcate and title the territory of the Awas Tingni and other indigenous communities in Nicaragua.

Despite the enormous difficulties that the Awas Tingni have faced in the implementation process of the judgment of the Inter-American Court (in fact, the community only received title to the lands in December 2008, more than seven years after the judgment), it must be acknowledged that this decision has opened the door to very progressive developments in terms of indigenous peoples' rights to their lands and territories, and a degree of empowerment for the indigenous peoples themselves in defence of their rights. In any case, as in many other contexts, there is a huge gap between, on the one hand, the formal recognition of indigenous peoples' rights and, on the other, the stark reality still faced every day as part of an unbridled struggle for access to natural resources. 


\section{REFERENCES}

ABU-LUGHOD, DEENA I. (2000). "Failed Buyout. Land Rights for Contra Veterans in Post-war Nicaragua”, Latin American Perspectives. Vol. 27, No. 3, pp. 32-62. DOI: https://doi.org/10.1177/0094582X0002700303

ACOSTA, MARÍA LUISA (2010). “Los Retos del Proceso de Titulación y Saneamiento como Protección a la Propiedad Indígena”. WANI: Revista del Caribe Nicaragüense, No. 60, January-March.

ALFRED-CUNNINGHAM, ANEXA B. (2011). "Derechos territoriales de los pueblos indígenas y comunidades afrodescendientes en Nicaragua", in APARICIO WILHELMI, MARCO (Ed.): Los derechos de los pueblos indígenas a los recursos naturales y al territorio. Icaria, Barcelona, pp. 203-222.

ALVARADO, LEONARDO J. (2007). "Prospects and Challenges in the implementation of Indigenous Peoples' Human Rights in International Law: Lessons from the Case of Awas Tingni vs. Nicaragua”. Arizona Journal of International\&Comparative Law, Vol. 24, $\mathrm{n}^{\circ} 3$.

ANAYA, JAMES S. and CAMPBELL, MAIA S. (2009). "Gaining Legal Recognition of Indigenous Land Rights: The Story of the Awas Tingni Case in Nicaragua”, in HURWITZ, DEENA R. and SATTERTHWAITE, MARGARET L. (Eds.). Human Rights Advocacy Stories, Foundation Press, New York.

BALUARTE, DAVID C. and DE VOS, CHRISTIAN M. (2010). From Judgment to Justice. Implementing International and Regional Human Rights Decisions. Open Society Justice Initiative, New York.

BROEGAARD, RIKKE y RIVAS, ÁLVARO (2007). “Introducción del libro Demarcación territorial de la propiedad comunal en la Costa Caribe de Nicaragua”. WANI: Revista del Caribe Nicaragüense, January-March.

BRUNNEGER, SANDRA (2007). El camino de Conflicto a Autonomía en Nicaragua: Lecciones Aprendidas. Minority Rights Group International, London.

COMITÉ EJECUTIVO DE LA CONADETI (2009). Informe Ejecutivo de la CONADETI y las CIDTs. Bilwi-RAAN, 10 December.

GÓMEZ ISA, FELIPE (2009). "Repairing Historical Injustices: Indigenous Peoples in Post-Conflict Scenarios”, in GÓMEZ ISA, F. and ORE AGUILAR, G. (Eds.). Rethinking Transitions. Equality and Social Justice in Societies Emerging From Conflict. Intersentia, Antwerp-Cambridge, 2011, pp. 265-300.

GÓMEZ ISA, FELIPE (2014). “Cultural Diversity, Legal Pluralism, and Human Rights from an Indigenous Perspective: The Approach by the Colombian Constitutional Court and the Inter-American Court of Human Rights”. Human Rights Quarterly, Vol. 36, pp. 723-756.

GONZÁlEZ, MIGUEL and FIGUEROA, DOLORES (2009). "Nicaragua multicultural: autonomía regional en la Costa Caribe”, in MARTI i PUIG, 
SALVADOR and CLOSE, DAVID (Eds.). Nicaragua y el FSLN (1979-2009). ¿Qué queda de la revolución?, Edicions Bellaterra, Barcelona.

HALE, CHARLES and GURDIÁN, GALIO (1998). Diagnóstico general sobre la tenencia de la tierra en las comunidades indígenas de la Costa Atlántica. Central American and Caribbean Research Council (CACRC), Blufields and Puerto Cabezas.

INTER-AMERICAN COURT OF HUMAN RIGHTS. Case of the Mayagna (Sumo) Awas Tingni Community v. Nicaragua. Judgment of August 31, 2001. Series C, no. 79.

JARQUÍN, LILLIAM (2003). "El nuevo marco jurídico de la propiedad comunal en la Costa Atlántica y los ríos Bocay, Coco, Indio y Maíz”. WANI: Revista del Caribe Nicaragüense, $\mathrm{n}^{\circ}$ 32, enero-marzo, pp. 6-18.

KECK, MARGARET E. and SIKKINK, KATHRYN (1998). Activists Beyond Borders. Advocacy Networks in International Politics. Cornell University Press, Ithaca.

MARTÍN BERISTAIN, CARLOS (2009). Diálogos sobre la reparación. Qué reparar en los casos de violaciones de derechos humanos. Ministerio de Justicia y Derechos Humanos, Quito.

MARTÍN, CLAUDIA and RODRÍGUEZ-PINZÓN, DIEGO (2013). Impacto nacional de los casos individuales del Sistema Interamericano de Derechos Humanos en materia de pueblos o comunidades indígenas.

MCLEAN CORNELIO, ESTHER MELBA (2004). El Caso Awas Tingni v. Nicaragua: Hacia el reconocimiento de los derechos de propiedad comunal indígena en la Costa Atlántica.

MCLEAN CORNELIO, ESTHER MELBA (2005). “La Falta de Implementación de la Sentencia de la Corte Inter-Americana de Derechos Humanos en el Caso Awas Tingni”, Seminario de Expertos de las Naciones Unidas sobre Implementación de Legislación y Jurisprudencia a nivel nacional relativa a los derechos de los pueblos indígenas: Experiencias de América. University of Arizona, Indigenous Peoples’ Law and Policy Programme, Tucson, 12-14 October.

MORGAN, RHIANNON (2004). “Advancing Indigenous Rights at the United Nations: Strategic Framing and Its Impact on the Normative Development of International Law”. Social Legal Studies, Vol. 13, pp. 481-500. DOI: https://doi.org/10.1177/0964663904047330

OPEN SOCIETY JUSTICE INITIATIVE (2011). From Judgment to Justice. Implementing International and Regional Human Rights Decisions. Open Society, New York.

Report of the Special Rapporteur on the situation of human rights and fundamental freedoms of indigenous people. Mr. Rodolfo Stavenhagen, E/CN.4/2006/78, 16 February 2006. 
RODRÍGUEZ GARAVITO, CESAR and RODRIGUEZ FRANCO, DIANA (2010). Cortes y cambio social: cómo la Corte Constitucional transformó el desplazamiento forzado en Colombia. Dejusticia, Bogotá.

RODRÍGUEZ-PIÑERO, LUIS (2004). “El caso Awas Tingni y el régimen de derechos territoriales indígenas en la Costa Atlántica de Nicaragua”, en AYLWIN, JOSÉ (Ed.). Derechos Humanos y Pueblos Indígenas. Tendencias internacionales y contexto chileno. Instituto de Estudios Indígenas-Universidad de La Frontera, Temuco.

WIGGINS, ARMSTRONG (2002). "El Caso Awas Tingni o el Futuro de los Derechos Territoriales de los Pueblos Indígenas del Caribe Nicaragüense”. WANI: Revista del Caribe Nicaragüense, $\mathrm{n}^{\circ}$ 30, Julio-Septiembre. 